\title{
ON THE EXPANSION OF FIXED OILS.
}

By W. T. Wenzel. Ph.M., M.D.*

THE relations existing between given volumes of liquids and their temperatures do not appear to follow such simple laws as apply in the case of gases. Whilst it is well known that in general the rate of expansion in every liquid is in direct proportion as the temperature rises, that also liquids expand most rapidly whose boiling points are lowest, and that isomeric compounds such as ethyl fomate and methyl acetate $\mathrm{C}_{3} \mathrm{H}_{6} \mathrm{O}_{2}$, ethyl propionate and methyl butyrate $\mathrm{C}_{5} \mathrm{H}_{10} \mathrm{O}_{2}$, etc., having the same boiling point, expand at the same or very nearly at the same ratio, yet, almost every liquid has a co-efficient of expansion different from that of any other liquid, and this co-efficient appears to vary to some extent with the changes of temperature; that is to say, that the rate of expansion is not uniform; a rule which holds good in all volatile liquids.

With the view of ascertaining whether fixed oils are governed by analagous laws, the writer concluded, inasmuch as he could not find data covering these, to investigate the subject. The methods usuaily followed for determining the cubical expansion of liquids may here be mentioned.

The actual expansion of any liquid may be ascertained by filling with it a small glass bottle whose cubical expansion is known, and weighing the bottle, with the quantity of liquid which fills it, at different temperatures. Another method which is more frequently used, and adopted by Pierre and Kopp in making their numerous determinations, is to observe the apparant expansion of the liquids in a so-called dilatometer, an instrument shaped like a common thermometer, and then correct these observations by taking into account the previously known cubical expansion of the glass.

It would be inaccurate to conclude that the expansion of a liquid between $0^{\circ}$ and $100^{\circ}$ amounted to one per cent. when the same quantity which filled 100 divisions at the former temperature occupied 101 divisions at the latter temperature, inasmuch as it is impossible to raise the temperature of a liquid without at the same time altering the capacity of the vessel in which it is contained. When a hollow vessel is heated its capacity increases exactly to the same extent as it would do if it was a solid mass of the same material and dimensions. Hence, we must consider the real or absolute expansion of liquids to be the apparent expansion, corrected for the simultanoous expansion of the vessel. These relations may be thus stated :-

The apparent expansion of a liquid is equal to the absolute expansion for the same interval of temperature diminished by the corresponding expansion of the containing vessel, and the co-efficient of absolute expansion in a vessel of any material is equal to the co-efficient of cubical expansion of the material of which the vessel is made. By

* Pharmaceutical Record. 
the co-efficient of expansion is understood the increase in volume of the substance expressed in vulgar or decimal fractions for every degree of temperature. The mean cubical expansion of glass at temperatures of from $0^{\circ}$ to $100^{\circ} \mathrm{C}$. is $\frac{1}{377_{34}}$ or 0.00002663 for each degree; hence these frations represent the co-efficients of expansion of this substance. Therefore, when once the cubical expansion of a vessel is known, the absolute expansion of any liquid can be easily deduced from its apparent expansion.

Six different samples of fixed oils were used in this investigation, three of which were of vegetable origin; the others were derived from the animal kingdom. For a dilatometer a glass flask of $510 \mathrm{c}$. cm. capacity was used, with a long neck graduated to one-tenth c. cm. at a temperature of $62^{\circ} \mathrm{F}$. The flask was filled with the oil to $\mathrm{O}$, and floated with the stem immersed in a double water bath, care being taken that the water bath and oils were exactly at $62^{\circ} \mathrm{F}$, a temperature easily obtained in San Francisco without artificial aids. The whole apparatus was covered with felt and woollen envelopes, and every care taken to insure an even temperature. Through the top of the felt covering holes were cut to allow the stem of the flask and thermometer to be raised for inspection.

The heat was applied by a diminutive coal oil lamp, so regulated that an expansion of the oil not to exceed $1 \mathrm{c}$. $\mathrm{cm}$. per hour was insured.

During the heating of the oils the flask was moved up and down about every five minutes, in order to heat the water surrounding it uniformly.

The following were the results obtained :-

\section{Olive Oil.}

\begin{tabular}{|c|c|c|c|c|c|c|}
\hline $\begin{array}{c}\text { Dila. } \\
\text { tometer. } \\
500 \mathrm{c.} \mathrm{cm} .\end{array}$ & $\begin{array}{l}\text { Ther- } \\
\text { mometer. } \\
62^{\circ} \mathrm{F} \text {. }\end{array}$ & $\begin{array}{l}\text { Differ. } \\
\text { ence. } \\
-\end{array}$ & $\begin{array}{r}D \\
\text { ton } \\
506\end{array}$ & $\begin{array}{l}\text { la. } \\
\text { eter. } \\
\text { c. } \mathrm{cm} \text {. }\end{array}$ & $\begin{array}{c}\text { Ther- } \\
\text { mometer. } \\
92^{\circ} \mathrm{F} \text {. }\end{array}$ & $\begin{array}{c}\text { Differ- } \\
\text { ence. } \\
5^{\circ}\end{array}$ \\
\hline 501 & $67^{\circ}$ & $5^{\circ}$ & 507 & ", & $97^{\circ}$ & $5^{\circ}$ \\
\hline $502 "$ & $72^{\circ}$ & $5^{\circ}$ & 508 & !, & $102^{\circ}$ & $5^{\circ}$ \\
\hline $503 "$ & $77^{\circ}$ & $5^{\circ}$ & 509 & $"$ & $107^{\circ}$, & $5^{\circ}$ \\
\hline 04 & $82^{\circ}$, & $5^{\circ}$ & 510 & $"$ & $112^{\circ}$, & $5^{\circ}$ \\
\hline 605 & $87^{\circ}$, & $5^{\circ}$ & & & & \\
\hline
\end{tabular}

\section{Mustard Seed Oil.}

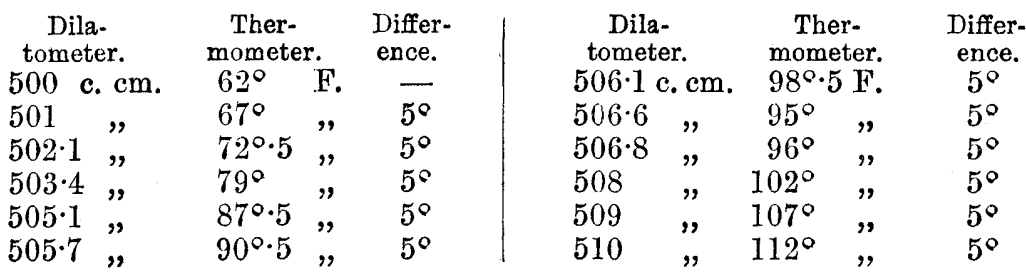

It will be seen that, although the above figures do not all give whole numbers, yet the expansion of mustard seed oil agrees with the olive oil, the expansion of each respectively being $1 \mathrm{c}$. cm. for every $50^{\circ} \mathrm{F} .: 72 \cdot 5^{\circ}-62^{\circ} \div 2 \cdot 1 \mathrm{c.} \mathrm{cm} .=5$.

\section{Cotton Seed Oil.}

\begin{tabular}{|c|c|c|c|c|c|}
\hline $\begin{array}{l}\text { Dila- } \\
\text { tometer. } \\
00 \mathrm{c.} \mathrm{cm} . \\
02 " \\
04 "\end{array}$ & $\begin{array}{c}\text { Ther- } \\
\text { mometer. } \\
62^{\circ} \mathrm{F} \text {. } \\
72^{\circ} " \\
82^{\circ} "\end{array}$ & $\begin{array}{c}\begin{array}{c}\text { Differ- } \\
\text { erence. }\end{array} \\
- \\
10^{\circ} \\
10^{\circ}\end{array}$ & $\begin{array}{c}\text { Dila. } \\
\text { tometer. } \\
506 \mathrm{c.} . \mathrm{cm} \text {. } \\
508 \% " \\
510 "\end{array}$ & $\begin{array}{c}\text { Ther- } \\
\text { mometer. } \\
92^{\circ} \mathrm{F} \text {. } \\
102^{\circ} " \\
112^{\circ} "\end{array}$ & $\begin{array}{c}\text { Differ- } \\
\text { ence. } \\
10^{\circ} \\
10^{\circ} \\
10^{\circ}\end{array}$ \\
\hline
\end{tabular}




$\begin{array}{lcc} & \text { Lard Oil. } & \\ \text { Dilatometer. } & \text { Thermometer. } & \text { Difference. } \\ 500 \mathrm{c.} \mathrm{cm} . & 62^{\circ} \mathrm{F} . & - \\ 510, & 112^{\circ}, & 50^{\circ} \\ & \text { Castor Oil. } & \\ \text { Dilatometer. } & \text { Thermometer. } & \text { Difference. } \\ 500 \mathrm{c.} \mathrm{cm} . & 62^{\circ} \mathrm{F} . & - \\ 510, & 112^{\circ}, & 50^{\circ} \\ & \text { Sperm Oil. } & \\ \text { Dilatometer. } & \text { Thermometer. } & \text { Difference. } \\ 500 \mathrm{c.} \mathrm{cm} . & 62^{\circ} \mathrm{F} . & - \\ 510, & 113^{\circ}, & 50^{\circ} \\ & \text { Cod Liver Oil. } & \\ \text { Dilatometer. } & \text { Thermometer. } & \text { Difference. } \\ 500 \mathrm{c.} \mathrm{cm} . & 62^{\circ} \mathrm{F} . & - \\ 510, & 112^{\circ}, & 50^{\circ}\end{array}$

These experiments show that $500 \mathrm{c}$. $\mathrm{cm}$. of either of these oils require $50^{\circ} \mathrm{F}$. to expand $10 \mathrm{c} . \mathrm{cm}$. or $5^{\circ} \mathrm{F}$. to expand $1 \mathrm{c}$. $\mathrm{cm}$. As the co-efficient of expansion is expressed in Centigrade degrees, therefore a reduction frcm Fahrenheit to Centigrade is necessary. $50^{\circ}-32^{\circ} \div 9 \times 5=10^{\circ} \mathrm{C}$.

Ten degrees C. increase $500 \mathrm{c} . \mathrm{cm}$. of oil to $510 \mathrm{c}$. $\mathrm{cm}$., which equals $1^{\circ} \mathrm{C}$. to each c. cm. in the $500 \mathrm{c}$. cm., hence $\frac{1}{50 \delta}=.0020000$ the apparent rate of expansion, and coefficient of apparent expansion,

In conclusion, the author would direct attention to facts elicited by this paper, that, unlike all volatile oils and liquids, the fixed oils made the subject of this paper have the same co-efficient of expansion, and that their rate of expansion is uniform for all degrees of heat from $62^{\circ}$ F. $\left(166^{\circ}\right.$ C. $)$ to $112^{\circ}$ F. $\left(44^{\circ} 4^{\circ}\right.$ C. $)$ 